\title{
Studi Literatur: Digitalisasi Dunia Pendidikan dengan Menggunakan Teknologi Augmented Reality pada Pembelajaran Matematika
}

\author{
Shafa Khairunnisa ${ }^{1, \text { a) }}$, Tian Abdul Aziz ${ }^{2, \text { b) }}$ \\ ${ }^{123}$ Universitas Negeri Jakarta, Rawamangun, Jakarta Timur \\ Email penulis: ${ }^{\text {a) }}$ shafakhairunnisa_1301617043@mhs.unj.ac.id, ${ }^{\text {b) }}$ tian_aziz@unj.ac.id
}

\begin{abstract}
The COVID-19 pandemic has both negative and positive impacts in the world of education. However, behind the negative impacts, there is a positive impact, that is building a digital learning environment where this is one of the characteristics of the industrial revolution era 4.0. Responding to the industrial era 4.0 and this pandemic, it's time for the education sector to utilize technology that will be make learning activities more effective and efficient, so that it can attract students' interest and motivation to learn. One of the ways to build education in the industrial era 4.0 is to use technology as a learning media, one of the technology that can be use is Augmented Reality (AR) technology. The purpose of this research are to explain what and how the use of AR technology, and its impact in increasing the motivation of students. The research method uses a qualitative approach and applies library research method or commonly referred to as literature studies (library research). In this research, sources are taken in the form of articles from journals that have been accredited by Sinta, researches restrict the journals from Sinta 1 to Sinta 4 and accredited by Scopus (Q1 to Q3). The analysis technique used in this research is content analysis technique. The conclusion of this research is that the Augmented Reality technology system has the potential to increase interest, motivation, and the result of a learning process, especially in mathematics learning. The existing learning system in Indonesia has not completely using technology as a learning media, so we need effort to build a learning system using technology, one of the technology that can be use is AR. By using $\mathrm{AR}$, it is expected that the learning motivation of students will increase.
\end{abstract}

Keywords: learning media, Augmented Reality, learning motivation, students, mathematics

\begin{abstract}
Abstrak
Pandemi COVID-19 ini memberikan dampak negatif maupun positif bagi dunia pendidikan. Namun, dibalik dampak-dampak negatif yang ditimbulkan, terdapat dampak positif bagi dunia pendidikan, yaitu membangun lingkungan belajar digital di mana hal tersebut merupakan salah satu ciri dari era revolusi industri 4.0. Menanggapi era industri 4.0 dan masa pandemi ini, sudah saatnya bidang pendidikan memanfaatkan teknologi yang nantinya akan menjadikan kegiatan pembelajaran lebih efektif dan efisien, sehingga dapat menarik minat dan motivasi belajar peserta didik. Salah satu cara untuk membangun pendidikan di era industri 4.0 ini adalah dengan memanfaatkan teknologi sebagai media pembelajaran, salah satu teknologi yang dapat dimanfaatkan adalah teknologi Augmented Reality (AR). Penelitian ini memiliki tujuan, yaitu berusaha untuk menjelaskan apa dan bagaimana penggunaan teknologi AR, serta dampaknya dalam meningkatkan motivasi peserta didik. Metode penelitian ini menggunakan pendekatan kualitatif dan menerapkan metode penelitian studi kepustakaan atau biasa disebut dengan studi literatur (library research). Pada artikel ini diambil sumber-sumber berupa artikel yang berasal dari jurnal yang sudah terakreditasi Sinta, peneliti hanya membatasi dari Sinta 1 s.d. Sinta 4 dan jurnal yang sudah terakreditasi Scopus (Q1 s.d. Q3). Teknik analisis yang digunakan dalam penelitian ini adalah teknik analisis isi (content analysis). Didapatkan kesimpulan bahwa sistem teknologi Augmented Reality memiliki potensi untuk meningkatkan minat, motivasi, dan hasil dari suatu proses pembelajaran, khususnya pada pembelajaran matematika. Sistem pembelajaran yang ada di Indonesia belum sepenuhnya memanfaatkan teknologi sebagai suatu media pembelajaran, maka diperlukan upaya untuk membangun sistem pembelajaran dengan menggunakan teknologi, salah satu teknologi yang dapat digunakan adalah AR. Dengan menggunakan AR diharapkan motivasi belajar peserta didik akan semakin meningkat.
\end{abstract}

Kata kunci: media pembelajaran, Augmented Reality, motivasi belajar, siswa, matematika

Copyright (c) 2021 Khairunnisa, Aziz

$\triangle$ Corresponding author:

Email Address: shafakhairunnisa_1301617043@mhs.unj.ac.id

Received 24 Februari 2021, Accepted 9 Agustus 2021, Published 20 Agustus 2021

https://doi.org/10.21009/jrpmj.v3i2.22267 


\section{PENDAHULUAN}

Masa pandemi COVID-19 yang terjadi pada saat ini menimbulkan perubahan yang cukup signifikan di seluruh bidang yang ada, khususnya pada bidang pendidikan. Seluruh tingkat satuan pendidikan terkena dampaknya. Sebelum terjadinya pandemi, peserta didik melakukan kegiatan pembelajaran secara normal, pembelajaran yang dilakukan dengan melakukan interaksi secara langsung antara peserta didik dengan peserta didik maupun peserta didik dengan guru. Terjadinya pandemi COVID-19 mengharuskan pembelajaran yang sebelumnya dilakukan secara normal (tatap muka), kemudian dialihkan menjadi Pembelajaran Jarak Jauh (PJJ), peralihan tersebut berdasarkan pada Surat Edaran Nomor 15 Tahun 2020 yang diterbitkan oleh Kementerian Pendidikan dan Kebudayaan (Kemendikbud) tentang pedoman penyelenggaraan belajar dari rumah pada masa pandemi. Di dalam surat edaran tersebut, dikatakan bahwa tujuan dari pelaksanaan Belajar Dari Rumah (BDR) atau yang saat ini kita kenal sebagai PJJ, yaitu memastikan hak peserta didik untuk mendapatkan pelayanan pendidikan selama pandemi berlangsung, melindungi seluruh bagian yang ada di dalam satuan pendidikan dari dampak buruk COVID-19, dan mencegah penyebaran COVID-19 di lingkungan pendidikan.

Pandemi ini memberikan dampak negatif maupun positif bagi dunia pendidikan. Dampak negatif ini tidak hanya dirasakan oleh peserta didik, namun orang tua peserta didik dan guru pun ikut merasakannya. Putri dan Purwanto (2020) menyatakan beberapa dampak yang dialami oleh peserta didik, orang tua, dan guru, yaitu kurangnya interaksi secara langsung (komunikasi dan sosialisasi) antara peserta didik, kemudian beberapa orang tua dan guru juga kurang memahami teknologi dengan baik, sehingga hal tersebut dapat menghambat potensi jalannya kegiatan PJJ ini (Setyorini, 2020). Namun, dibalik dampak-dampak negatif yang ditimbulkan, terdapat dampak positif bagi dunia pendidikan, yaitu membangun lingkungan belajar digital, dimana hal tersebut merupakan salah satu ciri dari era revolusi industri 4.0. Lingkungan di sini diartikan sebagai suatu bentuk interaksi peserta didik dengan lingkungannya, secara disadari atau tidak disadari, langsung maupun tidak langsung (Purwodani \& Praherdhiono, 2018), ilmu dan teknologi akan menjadi tumpuan pada era ini. Ditambah lagi dengan rumusan rangkaian Agenda Pembangunan Berkelanjutan 2030 atau yang sering disebut dengan Sustainable Development Goals (SDGs), di dalam rumusan tersebut terdapat tujuh belas tujuan pembangunan berkelanjutan, salah satunya adalah pendidikan yang berkualitas (SDG 04) (Badan Pusat Statistik, 2016). Pada poin SDG 04 ini terdapat tujuan yang ingin dicapai, salah satunya adalah membangun dan meningkatkan fasilitas pendidikan yang efektif bagi semua. Dengan tujuan atau target tersebut, guru harus bisa memanfaatkan teknologi agar dapat memberikan dampak yang positif bagi dunia pendidikan di era industri 4.0 ini.

Menanggapi era industri 4.0 dan masa pandemi ini, sudah saatnya bidang pendidikan memanfaatkan teknologi yang nantinya akan menjadikan kegiatan pembelajaran lebih efektif dan efisien, sehingga dapat menarik minat dan motivasi belajar peserta didik. Digitalisasi pada lingkungan 
belajar dapat dilakukan dengan cara menghubungkan secara langsung dengan aktifitas pembelajaran, yaitu dengan menggunakan media atau kegiatan pembelajaran berbasis internet, android, maupun perangkat-perangkat lainnya. Walaupun pembelajaran dilakukan secara digital atau daring, kegiatan pembelajaran harus dapat menumbuhkan minat dan motivasi yang tinggi dari peserta didik, sehingga nantinya peserta didik akan selalu antusias dalam melakukan pembelajaran dan memiliki rasa ingin tahu yang tinggi terhadap materi yang sedang mereka pelajari.

Dari uraian yang sudah disampaikan sebelumnya, salah satu cara untuk membangun pendidikan di era industri 4.0 ini adalah dengan memanfaatkan teknologi sebagai media pembelajaran, salah satu teknologi yang dapat dimanfaatkan adalah Augmented Reality (AR). Saat ini, teknologi AR sudah banyak digunakan dalam bidang gaming, kedokteran, pemasaran, militer, dan pendidikan (Chen, 2019). Terdapat banyak penelitian yang telah mengidentifikasi bahwa AR memiliki potensi yang sangat besar dalam meningkatkan proses pembelajaran dan pengajaran, seperti pada penelitian yang dilakukan oleh Yu-ching Chen (2019), Estapa \& Nadolny (2015), dan Evi Syahida, dkk. (2020), hasil dari ketiga penelitian tersebut akan disampaikan di bagian hasil dan pembahasan pada artikel ini. Media pembelajaran dengan AR memiliki manfaat dalam meningkatkan proses belajar serta minat peserta didik dalam belajar karena AR dapat memproyeksikan secara nyata dan melibatkan interaksi seluruh panca indera peserta didik (Mustaqim, 2016). Seperti yang dinyatakan oleh Teori Koehnert bahwa "semakin banyak indera yang terlibat dalam proses belajar, maka proses belajar tersebut akan menjadi lebih efektif" (Novitasari, 2016). Teori yang dinyatakan oleh Gagne dan Briggs (1970), memberikan implikasi bahwa media pembelajaran dapat meningkatkan daya belajar siswa karena rangsangan atau minat siswa untuk belajar. AR sebagai media pembelajaran yang dibuat semenarik mungkin serta komunikatif terhadap peserta didik, mengajak peserta didik untuk melakukan kegiatan multiindera (kegiatan yang dilakukan dengan melibatkan lebih dari satu indera) (Pangestu et al., 2019).

Oleh karena itu, peneliti ingin melihat beberapa hal mengenai teknologi AR itu sendiri, seperti apa itu teknologi AR? Bagaimana teknologi AR bekerja dalam meningkatkan motivasi peserta didik serta kualitas dari suatu pembelajaran? Apakah teknologi AR memiliki dampak yang signifikan dalam meningkatkan motivasi belajar peserta didik? Sudah saatnya bidang pendidikan menyadari perkembangan teknologi yang terjadi seiring dengan berkembangnya zaman, sehingga kegiatan pembelajaran dapat dilakukan dengan menggunakan teknologi seperti sistem teknologi AR yang akan dibahas pada artikel ini.

\section{METODE}

Peneliti menyadari bahwa kurangnya artikel yang membahas mengenai teknologi Augmented Reality (AR) yang dapat diimplementasikan pada bidang pendidikan di Indonesia, khususnya pada mata pelajaran matematika, maka penelitian ini memiliki tujuan, yaitu berusaha untuk menjelaskan apa dan bagaimana penggunaan teknologi AR, serta dampaknya dalam meningkatkan motivasi peserta didik. 
Metode penelitian ini menggunakan pendekatan kualitatif dan menerapkan metode penelitian studi kepustakaan atau biasa disebut dengan studi literatur (library research). Penelitian studi kepustakaan menurut Mestika Zed (2014) memiliki ciri utama, yaitu peneliti berhadapan langsung dengan sumber-sumber yang tersedia, pada artikel ini diambil sumber-sumber berupa artikel yang berasal dari jurnal yang sudah terakreditasi Sinta, peneliti hanya membatasi dari Sinta 1 sampai dengan Sinta 4 dan jurnal yang sudah terakreditasi Scopus (Q1 s.d. Q3), sumber-sumber yang digunakan oleh peneliti bersifat "siap pakai" yang memiliki arti peneliti tidak melakukan penelitian di lapangan, hanya berhadapan langsung dengan bahan sumber yang tersedia (Mestika Zed, 2014). Teknik analisis yang digunakan dalam penelitian ini adalah teknik analisis isi (content analysis). Dalam menjawab pertanyaan-pertanyaan yang ada pada bagian pendahuluan, maka dibutuhkan data, kemudian data-data tersebut dilakukan teknik analisis isi untuk dapat menjawab dan mendeskripsikannya.

\section{HASIL DAN PEMBAHASAN}

\section{Augmented Reality (AR)}

Augmented Reality (AR) dapat dianggap sebagai satu kesatuan rangakaian antara lingkungan nyata dengan lingkungan virtual. AR adalah salah satu jenis dari "mixed reality (MR)" di mana suatu objek digital atau objek yang berada di lingkungan virtual dimasukkan ke dalam lingkungan nyata, tidak seperti Augmented Virtuality, yaitu dimana objek atau konten yang ada di lingkungan nyata ditransformasikan ke lingkungan virtual.

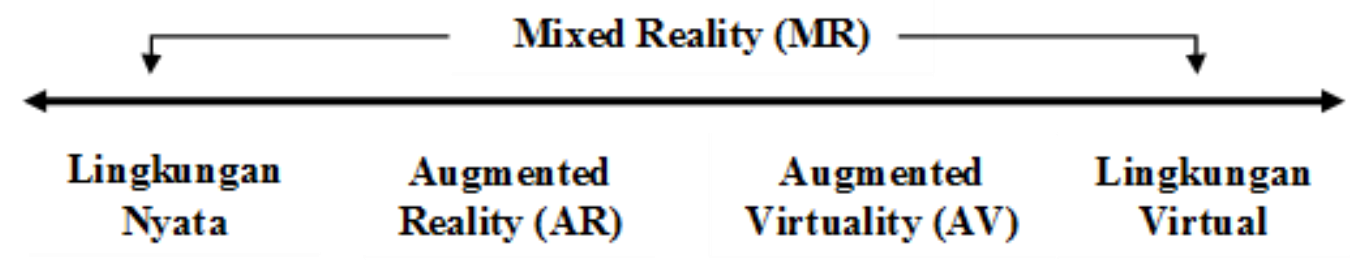

Gambar 1. Rangkaian lingkungan nyata - lingkungan virtual. (Sumber : Bower et al. 2014. Augmented Reality in education - cases, places, and potentials)

Thomas P. Caudell pada tahun 1990 dalam "The Term 'Augmented Reality"” memperkenalkan konsep AR untuk yang pertama kalinya. Terdapat tiga ciri yang menggambarkan bahwa teknologi tersebut menerapkan konsep AR (Balandin et al., 2010), yaitu :

a) Dapat menggabungkan antara lingkungan nyata dengan lingkungan virtual

b) Dapat menampilkan atau memberikan informasi secara interaktif dan real time atau seolah-olah objek virtual tersebut ada secara nyata

c) Dapat menampilkan objek virtual tersebut dalam bentuk tiga dimensi 
Kemudian, Azuma (1997) menyatakan ada beberapa syarat yang menjadi ciri utama suatu perangkat dapat dikatakan sebagai sistem AR, yaitu :

a) Terdapat kamera yang dapat merekam video untuk menangkap gambar secara langsung

b) Memiliki prosesor yang kuat untuk dapat menggabungkan objek virtual dengan lingkungan nyata atau dapat menampilkan objek 3D secara real time

c) Tampilan yang memungkinkan pengguna berinteraksi dengan objek virtual dan nyata

Dari penjelasan di atas, dapat disimpulkan bahwa Augmented Reality (AR) adalah suatu teknologi yang menggabungkan objek nyata dan virtual secara bersamaan di ruang yang sama dan berinteraksi secara real time atau seolah-olah objek virtual tersebut ada secara nyata (Bower et al., 2014). Menggabungkan dunia nyata dengan dunia virtual memberikan dampak yang berkesan dan bermakna secara konstektual. AR memungkinkan pengguna untuk melihat dunia nyata atau objek nyata secara virtual. Objek virtual yang memungkinkan untuk dimasukkan ke dalam sistem AR antara lain teks, gambar, model 3D, video, suara, maupun animasi. Menariknya, objek-objek virtual ini akan dianggap ada atau hidup berdampingan dalam lingkungan dunia nyata.

\section{Sistem teknologi Augmented Reality (AR) dalam meningkatkan motivasi peserta didik serta kualitas dari suatu pembelajaran}

Beberapa penelitian menunjukkan bahwa teknologi AR dapat membantu peserta didik dalam mengembangkan keterampilan dan pengetahuannya dengan cara yang lebih efektif (Estapa \& Nadolny, 2015), hal ini juga sejalan dengan tujuan yang ingin dicapai oleh SDG 04. Penggunaan teknologi AR merupakan salah satu upaya dalam meningkatkan kualitas lingkungan belajar dan AR dapat meningkatkan motivasi dan minat peserta didik, serta mampu menghasilkan suatu pemahaman yang lebih efektif dan lebih dalam terhadap suatu proses pembelajaran (Wu et al., 2013; Estapa \& Nadolny, 2015). Oleh karena itu, implementasi AR pada pembelajaran matematika bepotensi untuk meningkatkan aktivitas matematika, yaitu secara teknis maupun konseptual, disertai dengan peningkatan motivasi peserta didik.

Kemajuan pesat yang dialami pada teknologi dan fitur-fitur yang disediakan oleh gadget dan program lunak AR menyebabkan peningkatan ketersediaan dalam mengakses pendidikan. Sistem campuran yang dimiliki oleh teknologi AR dapat disebut juga sebagai sistem interactive print (Estapa $\&$ Nadolny, 2015). Saat ini, sistem tersebut dapat digunakan dengan menambahkan suatu penanda seperti QR codes, penanda tersebut menjadi bagian penting dari sistem interactive print yang berfungsi sebagai penghubung antara pengguna dengan konten AR yang terdapat di dalamnya. Seiring berjalannya waktu, fitur-fitur yang disediakan oleh gadget juga mengalami perkembangan, sehingga sistem tidak hanya dapat mengaktifkan konten AR hanya dengan menggunakan QR codes saja, tetapi sistem dapat mengenali tata letak dan desain halaman secara keseluruhan untuk mendeteksi dan 
mengidentifikasi dokumen mana yang menggunakan fitur teknologi AR, seperti terlihat pada gambar 2. Contohnya seperti pada halaman suatu buku ditambahkan gambar bangun ruang kubus, kemudian peserta didik dapat mengarahkan kamera yang ada pada gadget mereka ke halaman tersebut dan nantinya konten AR akan langung terlihat pada layar gadget mereka.
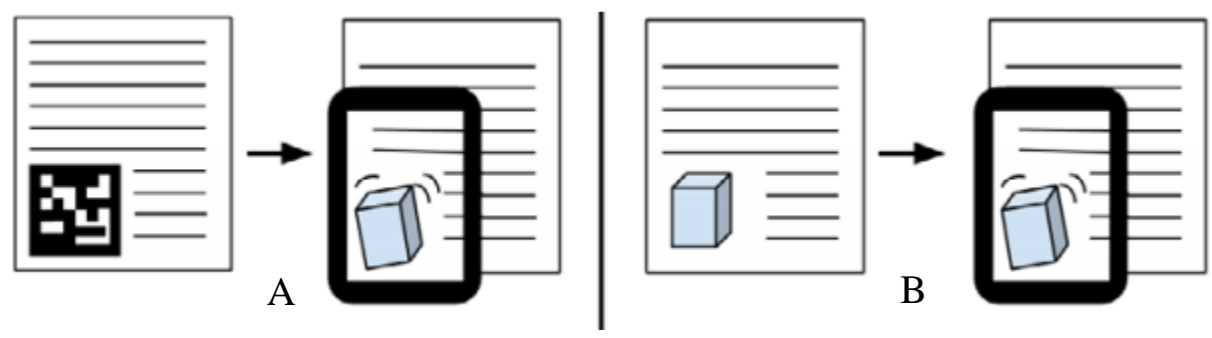

Gambar 2. A) AR dengan menggunakan QR Codes, B) AR dengan menggunakan gambar. (Sumber : Estapa \& Nadolny. 2015. The Effect of an Augmented Reality Enhanced Mathematics Lesson on Student Achievement and Motivation)

Bower et al. (2014) mengatakan bahwa terdapat beberapa literatur yang menunjukkan sistem teknologi AR dapat mendukung dan meningkatkan beberapa jenis pendekatan dalam suatu pembelajaran (Johnson et al., 2010; Shelton, 2002). Pendekatan pembelajaran yang dapat didukung oleh sistem teknologi AR antara lain :

a) Constructivist learning, dengan menggunakan teknologi AR, dimana AR dapat mendorong peserta didik untuk lebih terlibat dalam suatu proses pembelajaran. Selain itu, peserta didik juga dapat mendalami dan membuat koneksi antara pengetahua-pengetahuan dasar atau pengetahuan yang sudah mereka miliki sebelumnya (Kerawalla, Luckin, Seljeflot, \& Woolard, 2006)

b) Situated learning, pembelajaran kontekstual memungkinkan untuk dirasakan oleh peserta didik, jika suatu pembelajaran menumbuhkan pengalaman pendidikan dalam dunia nyata dan dengan membawa lingkungan dunia nyata ke dalam kelas (Chen \& Tsai, 2012; Dede, 2009; Dunleavy et al., 2009; Rasimah et al., 2011).

c) Games-based learning, sistem AR dapat digunakan untuk memfasilitasi suatu proses pembelajaran berbasis game yang menarik dengan cara membuat suatu narasi digital, kemudian menempatkan peserta didik pada suatu peran, dan menumbuhkan informasi yang relevan secara kontekstual. Sistem AR dapat mengubah lingkungan nyata ke dalam lingkungan virtual, dimana permainan yang dimainkan dapat menghasilkan keterampilan dalam mengaplikasikan pengetahuannya ke dalam lingkungan nyata dengan cara yang lebih sederhana dan mudah (Brom, Sisler, \& Slavik, 2020)

d) Enquiry-based learning, sistem AR menyediakan model virtual yang ditampilkan pada lingkungan nyata dan mudah untuk dimanipulasi. Kemudian AR juga sebagai pendukung dalam melakukan penyelidikan dengan cara menyajikan informasi yang relevan dan kontekstual dengan topik yang sedang dibahas (Johnson et al., 2010). 
Dari paparan di atas, dapat kita ketahui bahwa sistem teknologi AR dapat digunakan dan dimanfaatkan sebagai media pembelajaran, khususnya pada pembelajaran matematika. Hal tersebut juga sejalan dengan tujuan yang ingin dicapai pada era industri 4.0, yaitu digitalisasi di lingkungan pendidikan. Beberapa peneliti juga sudah melakukan penelitian dan membuktikan bahwa AR dapat meningkatkan motivasi, minat, dan hasil belajar peserta didik.

\section{Dampak dari penggunaan teknologi Augmented Reality (AR)}

Seperti pada penelitian yang dilakukan oleh Yu-ching Chen (2019), pada artikelnya disebutkan bahwa teknologi berkembang secara cepat seiring dengan perubahan zaman, salah satunya adalah teknologi AR yang memberikan pengalaman visual yang menarik kepada peserta didik dan AR juga memiliki potensi untuk merangsang lingkungan belajar dalam meningkatkan motivasi dan proses belajar serta mengurangi rasa kecemasan yang dirasakan peserta didik karena matametika. Motivasi merupakan faktor penting dalam proses pembelajaran (Chatzisarantis et al., 2015; Chen, 2019), peserta didik dengan motivasi tinggi akan lebih banyak terlibat dalam kegiatan pembelajaran yang mengarah pada proses yang lebih baik (Wu \& Tai, 2016; Chen, 2019). Kurangnya minat dan motivasi dalam pembelajaran matematika mungkin berasal dari kegagalan pembelajaran sebelumnya dan hal tersebut menyebabkan semakin meningkatnya rasa cemas pada pembelajaran matematika serta menimbulkan kepercayaan diri yang rendah (Ramirez et al., 2018; Chen, 2019). Dengan menggunakan model Keller's ARCS (Attention, Relevance, Confidence, dan Satisfaction) dapat meningkatkan kualitas desain pembelajaran yang terintegrasi dengan teknologi seperti penggunaan teknologi AR. Model tersebut memiliki empat faktor, yaitu:

a) Attention : dengan desain yang sesuai, bahan atau media pembelajaran dapat menarik perhatian peserta didik dan mendorong mereka untuk mengeksplorasi dan memahami suatu pembelajaran lebih dalam (Keller \& Suzuki, 2004; Chen, 2019).

b) Relevance : Peserta didik akan lebih termotivasi jika konten atau isi yang ada sesuai dengan tujuan, kebutuhan, dan pengalaman mereka (Keller \& Suzuki, 2004; Chen, 2019).

c) Confidence : semakin berhasil sebuah pengalaman belajar, peserta didik akan semakin termotivasi untuk meningkatkan kinerjanya dalam proses pembelajaran (Keller, 2008; Chen, 2019).

d) Satisfaction : Peserta didik akan lebih termotivasi, ketika mereka merasa bahwa pengalaman belajarnya berhasil dan memuaskan (Rodgers \& Withrow-Thorton, 2005; Chen, 2019).

Lingkungan belajar dengan menggunakan teknologi AR dan mengintegrasikan model Keller's ARCS dengan upaya membantu peserta didik, khususnya peserta didik yang memiliki kecemasan tinggi terhadap matematika, memiliki tujuan untuk meningkatkan motivasi dan prestasi belajar matematika serta menurunkan tingkat kecemasan belajar mereka. Penelitian ini menghasilkan bahwa peserta didik yang menggunakan Mobile AR (MAR) memiliki motivasi yang lebih tinggi, kinerja yang lebih baik, dan kecemasan yang lebih rendah dibandingkan dengan mereka yang tidak menggunakan MAR. Peserta 
didik yang menggunakan MAR menganggap sistem itu berguna, menyenangkan, dan mudah digunakan. Daya tarik visual dan pengalaman yang diberikan dalam fitur MAR yang biasanya tidak tersedia di dalam kelas pada pembelajaran matematika, membantu mereka yang memiliki tingkat kecemasan tinggi untuk mendorong pengalaman belajarnya. (Chen, 2019).

Hasil tersebut juga didukung oleh penelitian yang dilakukan oleh Anna Estapa dan Larysan Nadolny. Dalam penelitian tersebut, terdapat beberapa indikator yang dipakai, seperti : 1) Achievement test, menunjukkan bahwa skor yang dihasilkan pada kelompok eksperimen (dengan menggunakan AR) dan kelompok kontrol sama-sama mengalami peningkatan pada post-test dibandingkan dengan skor yang dihasilkan pada pre-test. 2) Motivation survey, kelompok yang menggunakan AR sebagai media pembelajaran setuju bahwa pembelajarannya lebih menarik dan dapat meningkatkan rasa ingin tahu yang lebih tinggi mengenai pembelajaran yang sedang mereka lakukan. 3) Open-ended question, salah satu komentar dari peserta didik mengenai proses pembelajarannya dengan menggunakan AR, mengatakan bahwa sangat senang dapat berinteraksi dengan matematika melalui teknologi. Kemudian, hasil penelitian yang telah dilakukan oleh Evi Syahida, Suprakarti, dan Aris Hadiyan menghasilkan media pembelajaran berbasis Android pada materi sistem koordinat yang mampu menyajikan materi sistem koordinat secara 3D dengan menggunakan teknologi AR, tidak hanya dalam tulisan dan gambar 2D saja. Penelitian tersebut juga menyatakan bahwa media pembelajaran dengan teknologi AR valid, hal tersebut menunjukkan bahwa media tersebut sudah layak dipakai dan dapat dilanjutkan pada uji coba skala besar. Uji coba skala kecil menunjukkan nilai rata-rata media sebesar 79,6\%, kemudian pada uji coba skala besar menunjukkan nilai rata-rata media sebesar $81,2 \%$, nilai tersebut meningkat dari uji coba skala kecil (Syahida et al., 2020).

\section{KESIMPULAN}

Berdasarkan rumusan-rumusan masalah yang sudah disebutkan sebelumnya, dapat disimpulkan bahwa Augmented Reality (AR) adalah suatu teknologi yang menggabungkan objek nyata dan virtual secara bersamaan di ruang yang sama dan berinteraksi secara real time atau seolah-olah objek virtual tersebut ada secara nyata. Implementasi AR pada pembelajaran matematika berpotensi untuk meningkatkan aktivitas matematika, yaitu secara teknis maupun konseptual, disertai dengan peningkatan motivasi peserta didik. Bower et al. (2014) mengatakan bahwa terdapat beberapa literatur yang menunjukkan sistem teknologi AR dapat mendukung dan meningkatkan beberapa jenis pendekatan dalam suatu pembelajaran (Johnson et al., 2010; Shelton, 2002). Pendekatan pembelajaran yang dapat didukung oleh sistem teknologi AR antara lain Constructivist learning, Situated learning, Games-based learning, dan Enquiry-based learning. Kemudian, penelitian yang dilakukan oleh YuChing Chen (2019), Anna Estapa dan Larysan Nadolny (2015), dan Evi Syahida, dkk. (2020) menghasilkan bahwa sistem teknologi Augmented Reality memiliki potensi untuk meningkatkan minat, motivasi, dan hasil dari suatu proses pembelajaran, khususnya pada pembelajaran matematika. 
Dengan menggunakan media pembelajaran yang inovatif seperti AR di mana AR memberikan pengalaman belajar yang berbeda, sehingga peserta didik dapat memperoleh pengalaman belajar yang relevan dan lebih luas di luar kelas, hal tersebut juga untuk mewujudkan pembelajaran yang dilakukan oleh peserta didik dapat didukung dengan penggunaan teknologi seiring dengan perkembangan zaman.

Pada artikel ini, peneliti hanya menggunakan sepuluh sumber yang berasal dari jurnal-jurnal yang berindeks Sinta maupun Scopus, sehingga disarankan untuk penelitian studi literatur selanjutnya dapat menggunakan lebih banyak lagi sumber yang tersedia. Kemudian, selama PJJ berlangsung dibutuhkan media pembelajaran yang bervariasi seperti memanfaatkan teknologi AR ini agar peserta didik tidak bosan selama belajar di rumah, teknologi AR dapat diimplementasikan pada modul belajar maupun lembar kerja peserta didik.

\section{UCAPAN TERIMA KASIH}

Penyusunan artikel ini tidak terlepas dari pihak-pihak yang telah memberikan bantuan, masukan, dan motivasi, sehingga penyusunan artikel ini dapat terselesaikan dengan baik. Pada kesempatan kali ini, penulis hendak menyampaikan ucapan terima kasih kepada:

1. $\quad$ Bapak Tian Abdul Aziz, Ph.D selaku dosen pembimbing

2. Teman-teman prodi pendidikan matematika B 2017 yang telah memberikan dukungan antara satu dengan yang lainnya.

\section{DAFTAR PUSTAKA}

Badan Pusat Statistik. (2016). Potret Awal Tujuan Pembangunan Berkelanjutan (Sustainable Development Goals) di Indonesia. In Katalog BPS.

Balandin, S., Oliver, I., Boldyrev, S., Smirnov, A., Shilov, N., \& Kashevnik, A. (2010). Multimedia services on top of M3 Smart Spaces. Proceedings - 2010 IEEE Region 8 International Conference on Computational Technologies in Electrical and Electronics Engineering, SIBIRCON-2010, 13(2), 728-732. https://doi.org/10.1109/SIBIRCON.2010.5555154

Bower, M., Howe, C., McCredie, N., Robinson, A., \& Grover, D. (2014). Augmented Reality in education - cases, places and potentials. Educational Media International, 51(1), 1-15. https://doi.org/10.1080/09523987.2014.889400

Chen, Y. C. (2019). Effect of Mobile Augmented Reality on Learning Performance, Motivation, and Math Anxiety in a Math Course. Journal of Educational Computing Research, 57(7), 1695-1722. https://doi.org/10.1177/0735633119854036

Estapa, A., \& Nadolny, L. (2015). The Effect of an Augmented Reality Enhanced Mathematics Lesson on Student Achievement and Motivation. Journal of STEM Education, 16(3), 40-49.

Gonzàlez, F., Villarejo, L., Miralbell, O., \& Gomis, J. M. (2012). How to use mobile technology and 
augmented reality to enhance collaborative learning on cultural and natural heritage? An elearning experience. Procedia Social and Behavioral Sciences XX New Trends on Global Education Conference North Cyprus, 2012, 0-0.

Mustaqim, I. (2016). Pemanfaatan Augmented Reality Sebagai Media Pembelajaran. Jurnal Pendidikan Teknologi Dan Kejuruan, 13(2), 174.

Novitasari, D. (2016). Pengaruh Penggunaan Multimedia Interaktif Terhadap Kemampuan Pemahaman Konsep Matematis Siswa. FIBONACCI: Jurnal Pendidikan Matematika Dan Matematika, 2(2), 8. https://doi.org/10.24853/fbc.2.2.8-18

Pangestu, A., Susanti, E., \& ... (2019). Pemanfaatan media pembelajaran berbasis augmented reality (AR) pada penalaran spasial siswa. Prosiding Seminar ..., 5(1), 88-93. http://prosiding.himatikauny.org/index.php/prosidinglsm/article/view/39

Purwodani, D. L., \& Praherdhiono, H. (2018). Prospek Pengembangan Lingkungan Belajar Digital untuk Generasi Z di Era Industri IV. Jurnal Pendidikan, 3, 930-934.

Setyorini. (2020). Terhadap Proses Pembelajaran Pada Kurukulum 13 ? Jiemar, 01(Juni), 95-102.

Syahida, E., Suprakarti, \& Hadiyan, A. (2020). Pengembangan Media Pembelajaran Matematika Menggunakan Smartphone Berbasis Android Dengan Teknologi Augmented Reality Pada Materi Sistem Koordinat Kelas VIII SMP. Prosiding Konferensi Nasional Penelitian Matematika Dan Pembelajarannya (KNPMP) V, 72-84.

Wulandari, R., Widodo, A., \& Diana, R. (2020). Penggunaan Aplikasi Augmented Reality Untuk Memfasilitasi Penguasaan Konsep dan Keterampilan Berpikir Kreatif Peserta Didik. Jurnal Pendidikan Biologi, 11(2), 59-69. https://doi.org/http://dx.doi.org/10.17977/um052v11i2p59-69

You, S., \& Neumann, U. (2010). Mobile augmented reality for enhancing E-learning and E-business. International Conference on Internet Technology and Applications, ITAP 2010 - Proceedings, 14. https://doi.org/10.1109/ITAPP.2010.5566168

How to cite : Khairunnisa, S., \& Aziz, T. A., 2021. Studi Literatur: Digitalisasi Dunia Pendidikan dengan Menggunakan Teknologi Augmented Reality pada Pembelajaran Matematika. Jurnal Riset Pendidikan Matematika Jakarta. 3(2). 54-63. https://doi.org/10.21009/jrpmj.v3i2.22267

To link to this article: $\underline{\text { https://doi.org/10.21009/jrpmj.v3i2.22267 }}$ 